\title{
Risk of Occurrence of Water Deficit in Soybean Cultivated in Lowland Soils
}

\author{
Mateus Possebon Bortoluzzi \\ University of Passo Fundo, Passo Fundo, Brazil \\ ARno BERnARdo Heldwein \\ Department of Plant Sciences, Federal University of Santa Maria, Santa Maria, Brazil \\ ROBERTO TRENTIN \\ Department of Plant Sciences, Federal University of Pelotas, Capão do Leão, Pelotas, Brazil \\ IVAN CARLOS MALDANER \\ Farroupilha Federal Institute of Education, Science and Technology, São Vicente do Sul, Santa Maria, Brazil \\ JOCÉlIA RosA DA SILVA ${ }^{\mathrm{a}}$ \\ Department of Plant Sciences, Federal University of Santa Maria, Santa Maria, Brazil
}

(Manuscript received 7 November 2019, in final form 25 August 2020)

\begin{abstract}
The occurrence of water deficit is intensified in lowland soils. Generating information with regard to its risk of occurrence is essential to avoid seed yield losses. The objective of this study was to determine the probability of water deficit in soybean cultivated in lowlands of the Vacacaí and Piratini River basins in the southern portion of Rio Grande do Sul in Brazil as a function of the sowing date. Soybean development was simulated considering three sets of cultivars of relative maturity groups (RMG) delimited by 5.9-6.8, 6.9-7.3, and 7.4-8.0, with a 10-day interval between the sowing dates making up the period between 21 September and 31 December. Daily meteorological data were used from 1971 to 2017 obtained from the Pelotas meteorological station and from 1968 to 2017 from the Santa Maria meteorological station. Water deficit (mm) in the subperiods and soybean development cycle was obtained from the calculation of evapotranspiration and daily sequential crop water balance. Data of water deficit were subjected to a probability distribution analysis, in which the exponential, gamma, lognormal, normal, and Weibull probability density function (pdf) adjustments were tested using chi-square and Kolmogorov-Smirnov adhesion tests, with a $10 \%$ significance level. The water deficit is lower in the Pelotas region than in Santa Maria. Sowings performed from 11 and 1 November present the lowest risk of occurrence of water deficit throughout the soybean cycle in Santa Maria and Pelotas, respectively. Risk of water deficit decreases for the beginning of flowering-beginning of seed (R1-R5) subperiod when soybean sowing occurs from the beginning of November.
\end{abstract}

KEYWORDS: Numerical analysis/modeling; Risk assessment Probability forecasts/models/distribution; Agriculture

\section{Introduction}

Soybeans are the most economically and socially prominent oleaginous crop in Brazil. The seed yield potential of soybeans is linked to the sowing date; thus, it is important to define it properly (Boyer et al. 2015; Zanon et al. 2016; Battisti et al. 2018; Silva et al. 2018). The sowing date also influences the water availability throughout the soybean cycle. Jointly with insufficient management practices, such as use of inappropriate cultivars, inadequate fertilization, and disease, pest and weed

\footnotetext{
a ORCID: 0000-0003-4446-4184.

Corresponding author: Mateus Possebon Bortoluzzi, mateusbortoluzzi@ upf.br
}

Earth Interactions is published jointly by the American Meteorological Society, the American Geophysical Union, and the Association of American Geographers. control are the two main factors responsible for the soybean yield gap in Brazil (Sentelhas et al. 2015; Battisti et al. 2018).

There was an expansion of soybean crop to the lowland areas in Rio Grande do Sul (RS), Brazil, during recent years, mainly because it composes a rotation alternative for weed control. Previously, the lowland areas were almost exclusively used for planting irrigated rice and pastures. Mundstock et al. (2017) pointed out a series of steps to enable viable soybean farming in lowland areas, including the sowing date, that do not entail costs to the grower, and they define several practices to be adopted during the crop cycle.

A soybean crop with high productivity potential requires about $800 \mathrm{~mm}$ of water throughout the crop cycle to express its potential (Zanon et al. 2016). Moreover, the periods in which the plants are subject to water deficit in the state of Rio Grande do Sul are frequent because of the rain spatial and temporal variability. In addition, the plants are exposed to greater periods of water deficiency in the lowlands as a result of decreased water storage capacity of these soils (Rocha et al. 2017). 
The water deficit determines the reduction of the leaf osmotic and total potential as well as stomatal conductance and transpiration (Sionit and Kramer 1977; Villalobos-Rodriquez and Shibles 1985; Wijewardana et al. 2018), decreasing the cellular turgor and growth rate. Also, reduced leaf area index and plant height is observed (Eck et al. 1987).

The seed yield reduction intensity depends on the development stage, magnitude, and period of occurrence of water deficit. Karam et al. (2005) verified that about $65 \%$ of the water consumed during the soybean cycle occurs between the beginning of pod (R3) and beginning of seed (R5) stages, and there was a reduction in seed yield when the plants were subjected to two weeks of water deficit in stage R5. However, the yield reduction was not verified when the same period of stress was applied from the full flowering (R2) stage, showing a compensatory effect among the soybean yield components and capacity to recover from moisture stress (Karam et al. 2005). The seed number and especially the seed weight of soybeans can be reduced substantially in the event of water deficit during seed filling (Sionit and Kramer 1977). Eck et al. (1987) observed a seed yield reduction of $9 \%-13 \%$ by subjecting the plants to water deficit from the beginning of flowering (R1) to the R2 and R3 stages. Nevertheless, seed yield was reduced from $15 \%$ to $46 \%$ when stress was applied between the R5 and full seed (R6) stages.

Simulation of soybean development at different sowing dates coupled with daily sequential water balance (SWB) calculation makes it possible to obtain water deficit data over a considerable number of agricultural years. Subjecting these results to probability analysis enables acquiring the risk magnitude for different sowing dates and subperiods of the crop development.

The analysis of the risk of occurrence of water deficit using daily data allows us to identify critical levels that would not be verified through determinations at monthly or decadal dates. The daily probability analysis is not considered for the definition of the soybean sowing schedule in RS state and Brazil that is extremely important for accessing the credit financial system. In addition, knowledge of the risk associated with the soybean sowing date may contribute to the area of agricultural security, which has a great growth potential.

The objective of this study was to determine the climatic risk of occurrence of water deficit in different subperiods and in the soybean development cycle as a function of the sowing date, considering the water storage capacity of representative lowland soils of the Vacacaí and Piratini River basins in the southern portion of RS state.

\section{Material and methods}

The daily meteorological data of air temperature, relative air humidity, wind speed, insolation and rainfall required for simulation of soybean development and for SWB were collected from Pelotas meteorological station located in the municipality of Capão do Leão, RS, southern Brazil (31 $52^{\prime} \mathrm{S}$, $52^{\circ} 21^{\prime} \mathrm{W}$ at $13.2 \mathrm{~m}$ in altitude), from September 1971 to June 2017 (with missing data from June 1989 to August 1991) and at the main meteorological station of Santa Maria, RS, Brazil $\left(29^{\circ} 43^{\prime} 23^{\prime \prime} \mathrm{S}, 53^{\circ} 43^{\prime} 15^{\prime \prime} \mathrm{W}\right.$, at $95 \mathrm{~m}$ in altitude), from September 1968 to June 2017, for a total of 46 and 49 agricultural years, respectively (Fig. 1). According to the Köppen climate classification, the climate of the region is subtropical humid (Cfa) with warm summers and without dry season defined (Alvares et al. 2013).

The soybean plant development was simulated in decadal sowings (S) for the period between 21 September and 31 December, according to the method proposed by Trentin et al. (2013). In this method, thermal time was calculated to estimate the emergence date (EM), and the cumulative value of $92.5^{\circ} \mathrm{C}_{\text {day }}{ }^{-1}$ was adopted, beginning from the base temperature of $10^{\circ} \mathrm{C}$ (Schneider et al. 1987) and using the daily mean air temperature $T$, which was obtained from the arithmetic mean of daily maximum temperature $\mathrm{Tx}$ and daily minimum temperature Tn. Occurrence date of the first trifoliate leaf emission stage (V2) was estimated using the Soydev model (Setiyono et al. 2007), using coefficients obtained by Streck et al. (2009).

The R1 date was simulated with the nonlinear model of development response to air temperature and with photoperiod proposed by Sinclair et al. (1991), using different coefficients according to the maturity group. The occurrence date of R5 stage was estimated by the model proposed by Sinclair et al. (2007), using linear regression based on photoperiod and variable coefficients according to the maturity group.

The date of physiological maturity (R7) stage was simulated from the date of R5 stage occurrence by calculating the thermal time and adopting the base temperature of $10^{\circ} \mathrm{C}$ and the accumulated thermal time of $554^{\circ} \mathrm{C}$ day (Martorano et al. 2012). The date of harvest maturity (R8) was simulated by the model proposed by Sinclair (1986), without the water deficit response function in the algorithm and the plastochron values obtained by N. A. Streck et al. (2008).

The cultivars were grouped according to their relative maturity group (RMG), forming three sets with RMG between 5.9 and 6.8, 6.9 and 7.3, and 7.4 and 8.0. This RMG amplitude was used to represent most of the cultivars currently used in lowland areas in the southern portion of Rio Grande do Sul, for instance, NA 5909 RR and TECIRGA 6070 RR (RMG 6.3), BRS 246 RR (RMG 7.2), and TEC 7849 IPRO (RMG 7.8).

For the SWB calculation, the method proposed by Thornthwaite and Mather (1955) described by Pereira et al. (1997) was used. Daily values of rainfall, soybean crop evapotranspiration (ETc), and water storage capacity (WSC) of the soil were used to obtain real evapotranspiration and water deficit. To do this, the reference evapotranspiration (ETo) was estimated using the Penman-Monteith method (Allen et al. 1998). To obtain the ETc, the Kc values recommended by the FAO for soybean crop (Allen et al. 1998) were considered constant during the subperiods S-V2 (0.40) and beginning of flowering-beginning of seed (R1-R5) (1.15). In the first trifoliate leaf-beginning of flowering (V2-R1) subperiod, Kc was calculated as a function of the development rate (SD) variation (Sinclair et al. 1991) and in the beginning of seed-physiological maturity (R5-R7) subperiod as a function of the thermal time of this subperiod (Martorano et al. 2012). Kc value of 0.50 was used for the physiological maturity-harvest maturity (R7-R8) subperiod.

The representative soils of the lowlands of the river basins of Vacacaí River in the Santa Maria region and the Piratini River in the Pelotas region are classified as Planosol Haplic Eutrophic arenic and Planosol Haplic Eutrophic vertisolic, respectively (E. V. Streck et al. 2008). The WSC of the soils was calculated 


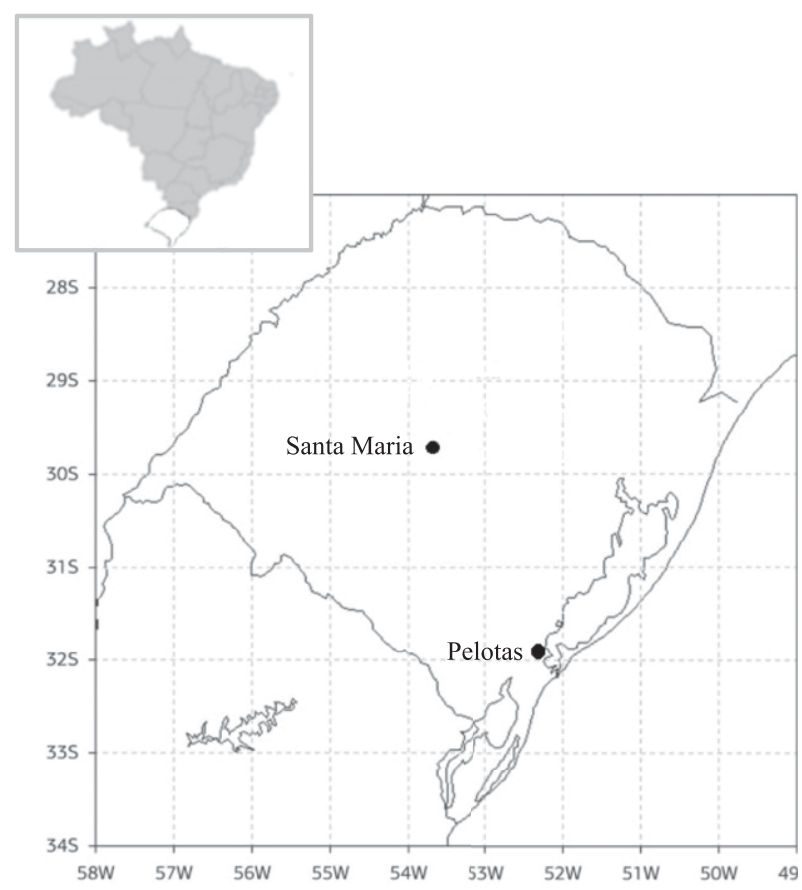

FIG. 1. Map of the RS state. Solid circles indicate locations of meteorological stations. The inset map indicates the location of RS within Brazil.

[Eq. (1)] using the values of microporosity and permanent wilting point obtained up to $30-\mathrm{cm}$ depth by Gubiani et al. (2018) and Ribeiro et al. (2016) for Santa Maria and Pelotas, respectively.

The initial WSC $\left(\mathrm{WSC}_{i}\right)$ was determined for the $0-0.10 \mathrm{~m}$ layer because the root system generally does not exceed this dept until the V2 stage. For the V2-R1 subperiod, a sigmoidal growth curve for the root system proposed by Dourado Neto et al. (1999) as a function of SD (Sinclair et al. 1991) was used [Eq. (2)]. The final WSC ( $\mathrm{WSC}_{f}$ ) was calculated for the $0-0.30 \mathrm{~m}$ layer because of the strong restriction on root growth for deeper layers in lowlands (Gubiani et al. 2018). The calculated $\mathrm{WSC}_{i}$ and $\mathrm{WSC}_{f}$ were $23 \mathrm{~mm}$ and 66 and $63 \mathrm{~mm}$, respectively, for the soils of the Santa Maria and Pelotas regions:

$$
\begin{aligned}
\mathrm{WSC} & =\left(\theta_{\text {mic }}-\theta_{\mathrm{pwp}}\right) \mathrm{Z} \quad \text { and } \\
\mathrm{WSC}_{n} & =\mathrm{WSC}_{i}+\left(\mathrm{WSC}_{f}-\mathrm{WSC}_{i}\right)^{-2}[1-\cos (\pi \times \mathrm{SD})],
\end{aligned}
$$

where WSC is the water storage capacity of the soil (mm), $\theta_{\text {mic }}$ is the volumetric content of water corresponding to the soil microporosity $\left(\mathrm{mm}^{3} \mathrm{~mm}^{-3}\right), \theta_{\text {pwp }}$ is the volumetric content of water in the permanent wilting point $\left(\mathrm{mm}^{3} \mathrm{~mm}^{-3}\right), Z$ is the root system depth along the cycle $(\mathrm{mm}), \mathrm{WSC}_{n}$ is WSC in the day $n, \mathrm{WSC}_{i}$ is the initial WSC, $\mathrm{WSC}_{f}$ is the final WSC, and SD is the soybean plant development rate.

The daily water deficit ( $\mathrm{mm}$ ) was obtained by the difference between the soybean crop evapotranspiration (ETc) and the soybean real evapotranspiration (ETr). The water deficit data obtained for the different sowing dates, RMGs, and years of the historical series of meteorological data were subjected to probability distribution analysis and test to verify the probability density function (pdf) that best represents the data distribution. The exponential, gamma, lognormal, normal, and Weibull pdf adjustments were tested using the chi-square and Kolmogorov-Smirnov adhesion tests, with $10 \%$ error probability. After pdf fit, the values of occurrence probability for at least $50,75,100$, and $150 \mathrm{~mm}$ of water deficit were calculated during the soybean cycle and for 5, 10, 25, 50, and $75 \mathrm{~mm}$ in each development subperiod.

\section{Results and discussion}

Regardless of the location, the lognormal pdf presented the best fit for the water deficit data in the soybean development cycle. The occurrence risk of water deficit estimated by means of the pdfs was higher for Santa Maria than for Pelotas region (Fig. 2). We can infer that, independently of RMG, at least $50 \mathrm{~mm}$ of water deficit can occur in practically every year of soybean cycle, except for 21 December and 31 December sowing dates in Santa Maria (Figs. 2a,c,e) and excepting all December sowings in Pelotas (Figs. 2b,d,f), where there is a risk reduction. According to Karam et al. (2005) and Zanon et al. (2016), the soybean crop can utilize above than $700 \mathrm{~mm}$ of water throughout the crop cycle, but in most years the total rainfall that occurs during the soybean crop season in these two sites of RS state is lower.

For the water deficit (WD) level of $75 \mathrm{~mm}$ in the soybean cycle, the probability of occurrence $p$ decreases from 21 and 1 November, respectively, for Santa Maria and Pelotas (Fig. 2). Similar results were obtained by Nied et al. (2005) in maize, where there was greater water deficit during the development cycle for sowing between 1 October and 15 November in Santa Maria. Silva et al. (2011) also observed a greater irrigation requirement for common bean in sowings performed in the first half of November.

The risk of WD accumulating over $100 \mathrm{~mm}$ is greater than $80 \%$ in the soybean cycle when sowing is performed until 11 November in the Vacacaí River basin in the Santa Maria catchment area (Figs. 2a,c,e) and until 21 October in the Piratini River basin in the Pelotas coverage area (Figs. 2b,d,f). The risk of $150 \mathrm{~mm}$ of WD occurs between $50 \%$ and $60 \%$ of the years in the first five sowing dates and then decreases to less than $30 \%$ of the years in December sowing dates in the lowland soils of the Vacacaí River (Figs. 2a,c,d). These results agree with those observed by Cunha et al. (2001), mainly for the southern portion of RS, where sowing carried out until 15 November presents the highest probability of seed yield potential losses as a function of water deficit.

In the Piratini River basin, the risk of WD occurrence is lower than $45 \%$ in the first four sowing dates, with a null risk trend in the last December sowing dates for all soybean RMGs (Figs. 2b,d,f). Nevertheless, Zanon et al. (2016) reported that the two main factors governing soybean yield are water supply and photothermal coefficient $Q$, mainly between soybean R3 and $\mathrm{R} 7$ stages $\left(Q_{\mathrm{R} 3-\mathrm{R} 7}\right)$. Therefore, despite the lower risk associated with sowing in December, the $Q_{\mathrm{R} 3-\mathrm{R} 7}$ decreases as sowing time progresses, which diminishes the soybean yield potential (Zanon et al. 2016).

The response to $Q_{\mathrm{R} 3-\mathrm{R} 7}$ is more pronounced in irrigated than nonirrigated conditions, which demonstrates the influence of 


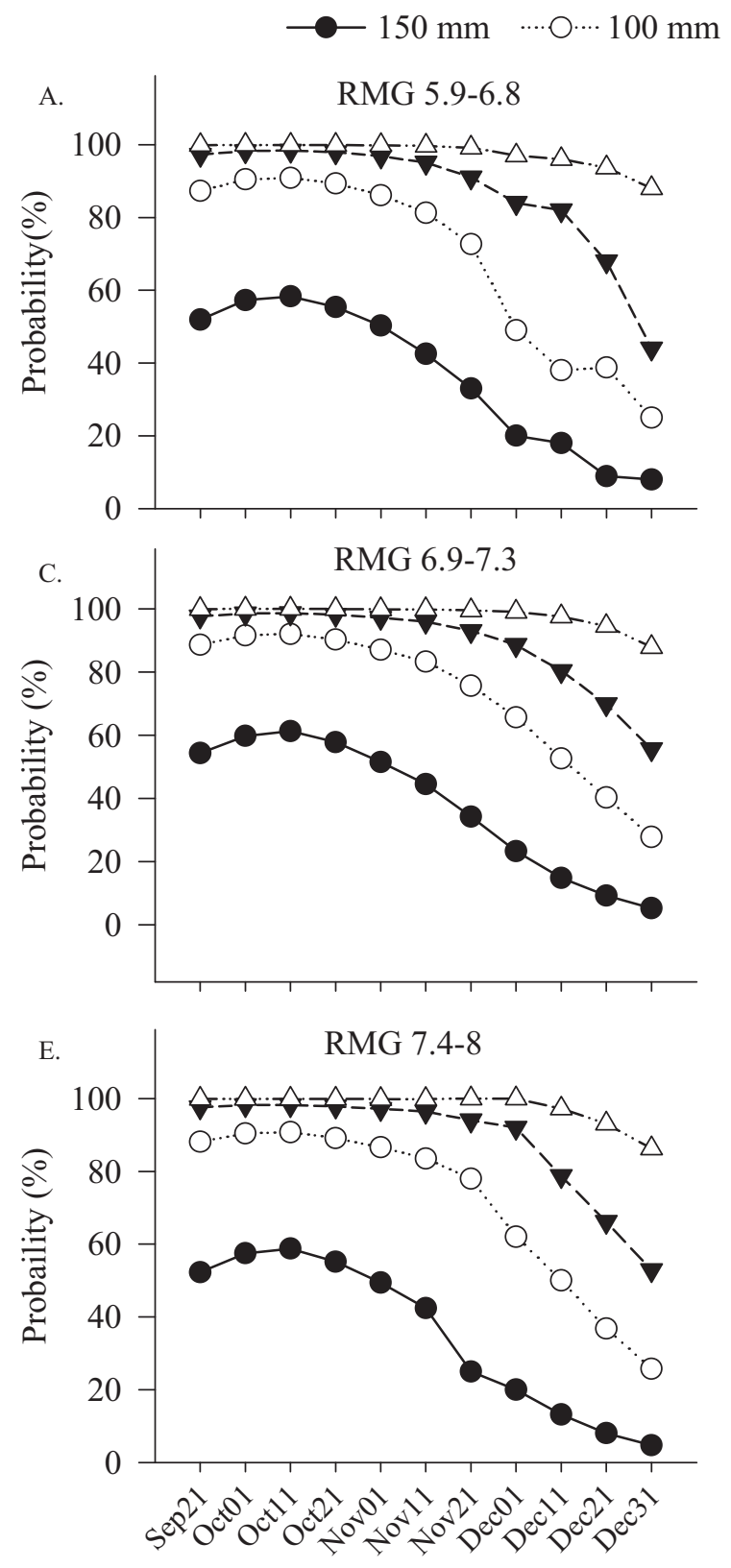

Sowing dates
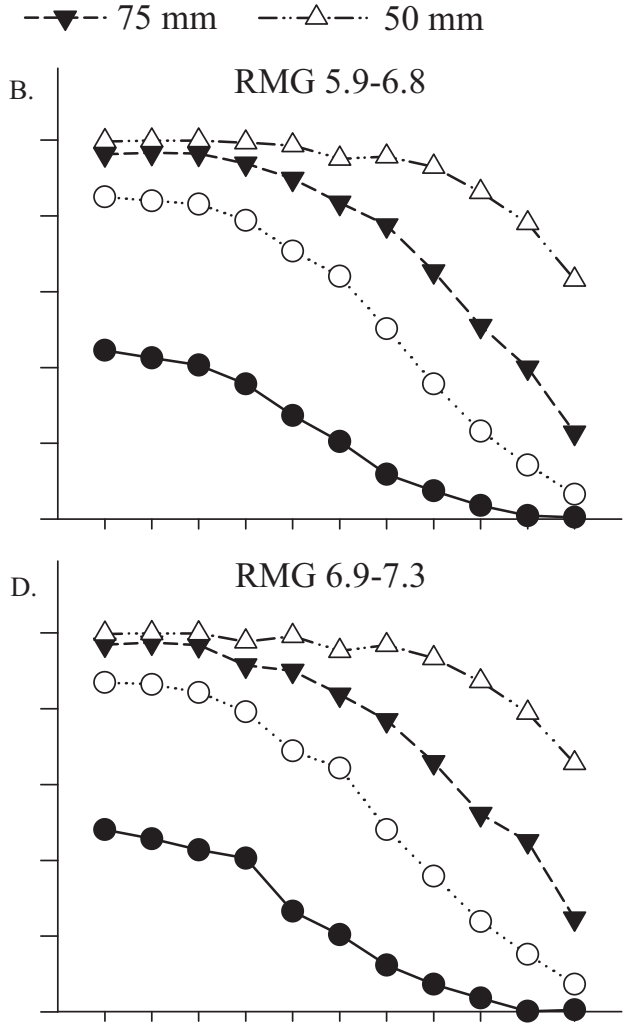

F.

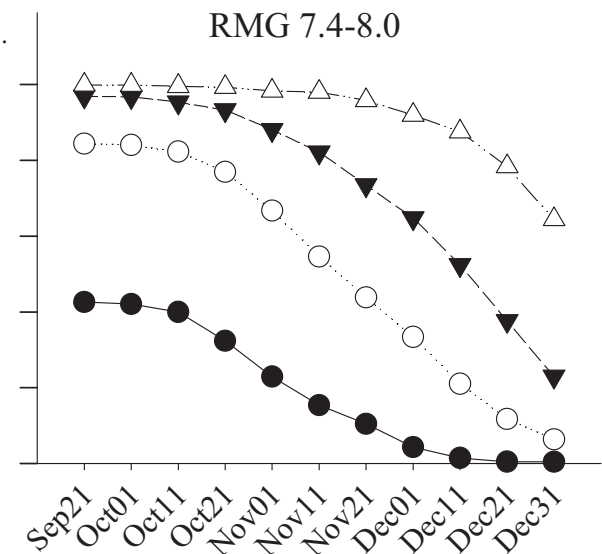

Sowing dates

FIG. 2. Probability of occurrence of water deficit equal or greater than $50,75,100$, and $150 \mathrm{~mm}$ during the soybean development cycle of RMG (a),(b) 5.9-6.8, (c),(d) 6.9-7.3, and (e),(f) 7.4-8.0 in the (left) Vacacaí and (right) Piratini River basins, considering 11 sowing dates simulated in each year from 1968 to 2017 in Santa Maria and from 1971 to 2017 in Pelotas.

water availability on crop yield (Zanon et al. 2016). Thereby, an adequate balance must be sought between the water availability and the photothermal coefficient to obtain the highest yield potential associated with the lower risk of yield loss as a function of the water deficit in the development cycle and subperiods.

In both locations, gamma, lognormal, and exponential pdf were the ones that exhibited the best adjustment for water deficit data in the subperiods. The risk of water deficit occurrence in the sowing-emergence (S-EM) subperiod is greater for sowing dates near the summer solstice because of higher energy (radiation balance) availability, utilized for soil heating and soil water evaporation, among other processes. The occurrence probability of $5 \mathrm{~mm}$ of water deficit at different sowing dates is not greater than $43 \%$ for Santa Maria (Figs. 3a, 4a, and 5a) and $23 \%$ for Pelotas (Figs. 3c, 4c, and 5c). Although considering a specific agricultural year, sowing date is defined primarily as a 


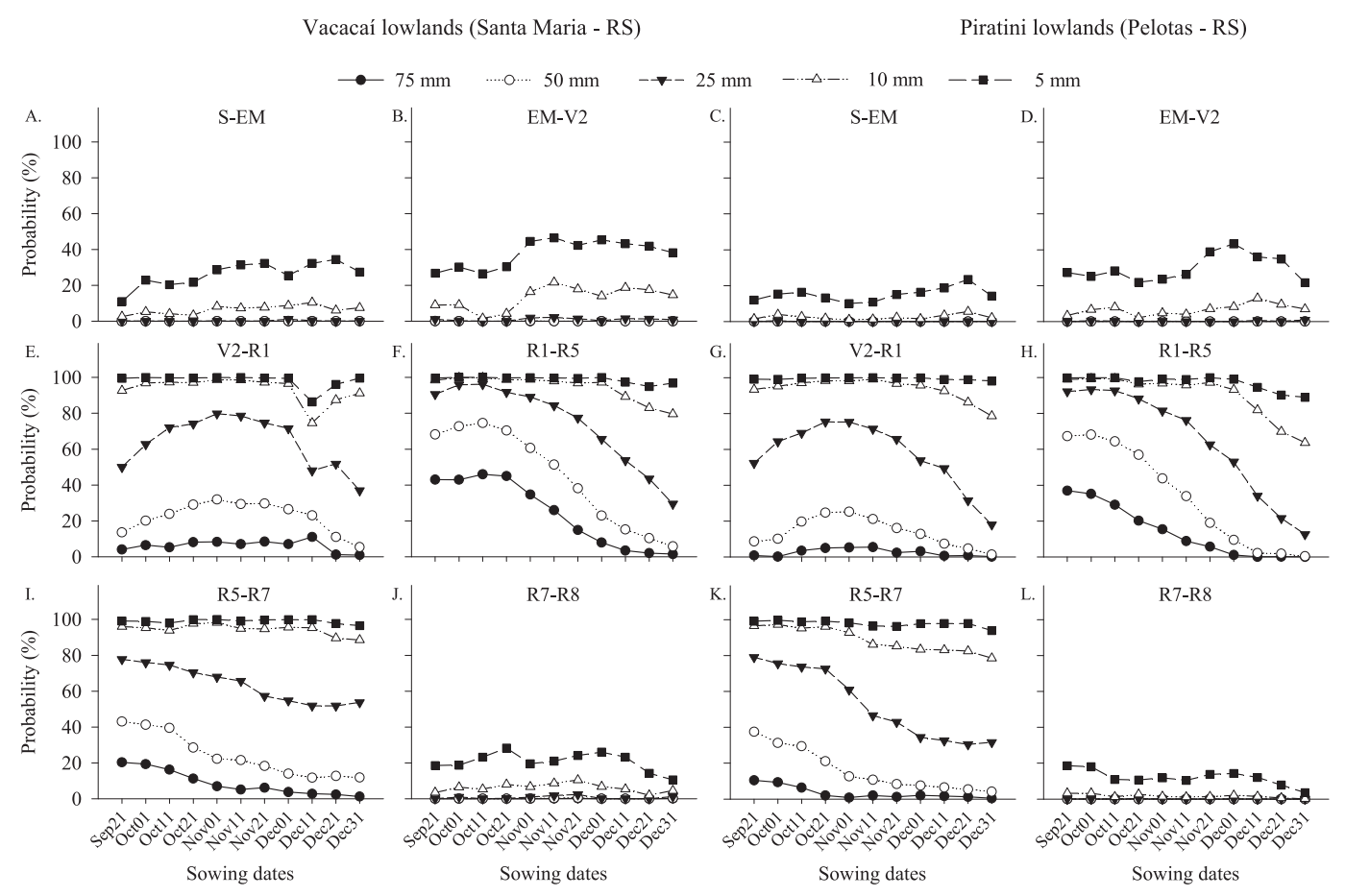

FIG. 3. Probability of occurrence of water deficit equal or greater than $5,10,25,50$, and $75 \mathrm{~mm}$ accumulated during the soybean development subperiods sowing-emergence (S-EM), emergence-first trifoliate leaf (EM-V2), first trifoliate leaf-beginning of flowering (V2-R1), beginning of flowering-beginning of seed (R1-R5), beginning of seed-physiological maturity (R5-R7) and physiological maturity-harvest maturity (R7-R8) of relative maturity group 5.9-6.8 in lowlands of the (a),(b),(e),(f),(i),(j) Vacacaí and (c),(d),(g),(h),(k),(l) Piratini river basins in 11 sowing dates simulated in each year from 1968 to 2017 in Santa Maria, RS and from 1971 to 2017 in Pelotas, RS.

function of the soil moisture availability at the time of sowing rather than climate risk values obtained from a historical series.

The trend is also similar for the emergence-first trifoliate leaf (EM-V2) subperiod, with sowing dates after 1 November presenting a higher risk, especially for the levels of 5 and $10 \mathrm{~mm}$, independently of RMG for Santa Maria region (Figs. 3b, $4 \mathrm{~b}$, and $5 \mathrm{~b}$ ). Considering the Pelotas region, the probability values are smaller and there is increased risk from 21 November (Figs. 3d, 4d, and 5d).

For the Santa Maria catchment area, the probability values of at least 5 and $10 \mathrm{~mm}$ in the $\mathrm{V} 2-\mathrm{R} 1$ subperiod are close to $100 \%$ in all sowing dates of all RMG, except for simulated sowing of 11 December for RMG 5.9-6.8 (Fig. 3e). In this specific case, the adjusted pdf was the exponential unlike the previous sowing dates in which the gamma pdf presented the best fit, which generated this abrupt variation in the estimated probability values. The same occurred for the simulation of 21 December sowing date in Pelotas for RMG 6.9-7.3 (Fig. 4g). In addition, the 21 December and 31 December sowing dates exhibited a slight reduction in the occurrence probability of $10 \mathrm{~mm}$ or more of water deficit for both RMG 5.9-6.8 (Fig. 3g) and RMG 7.4-8.0 (Fig. 5g) in the same location.
Differentiation of sowing dates and RMG with lower WD risk in the vegetative subperiod V2-R1 can be verified by assessing water deficit levels above 25,50 , and $75 \mathrm{~mm}$, where sowing from 1 November and RMG 7.4-8.0 (Fig. 5e) presented the highest probability of water deficit for Santa Maria. However, we can delimit a sowing window with a higher risk between 11 October and 1 December for RMG 5.9-6.8 (Fig. 3e) and between 11 October and 21 November for RMG 6.9-7.3 (Fig. 4e) and 7.4-8.0 (Fig. 5e).

Similar results for the V2-R1 subperiod were observed for the lowlands of the Piratini River areas, but with a lower magnitude of the probability values, which demonstrates the lower occurrence of water deficit in comparison with Santa Maria. There is a marked reduction in the occurrence risk of water deficit in this subperiod for sowing after 21 November for all RMGs (Figs. 3g, 4g, and 5g). Considering that the WSC of the soils is similar, this reduction probably occurred due to the lower atmospheric demand. For instance, the daily mean maximum evapotranspiration of the crop was 0.35 to $1.14 \mathrm{~mm}$ lower in Pelotas than in Santa Maria in October and January, respectively. The accumulated difference in evapotranspiration was of $147 \mathrm{~mm}$ from October to March.

Considering the R1-R5 subperiod in the Santa Maria catchment region, the highest risk of WD occurrence coincides 


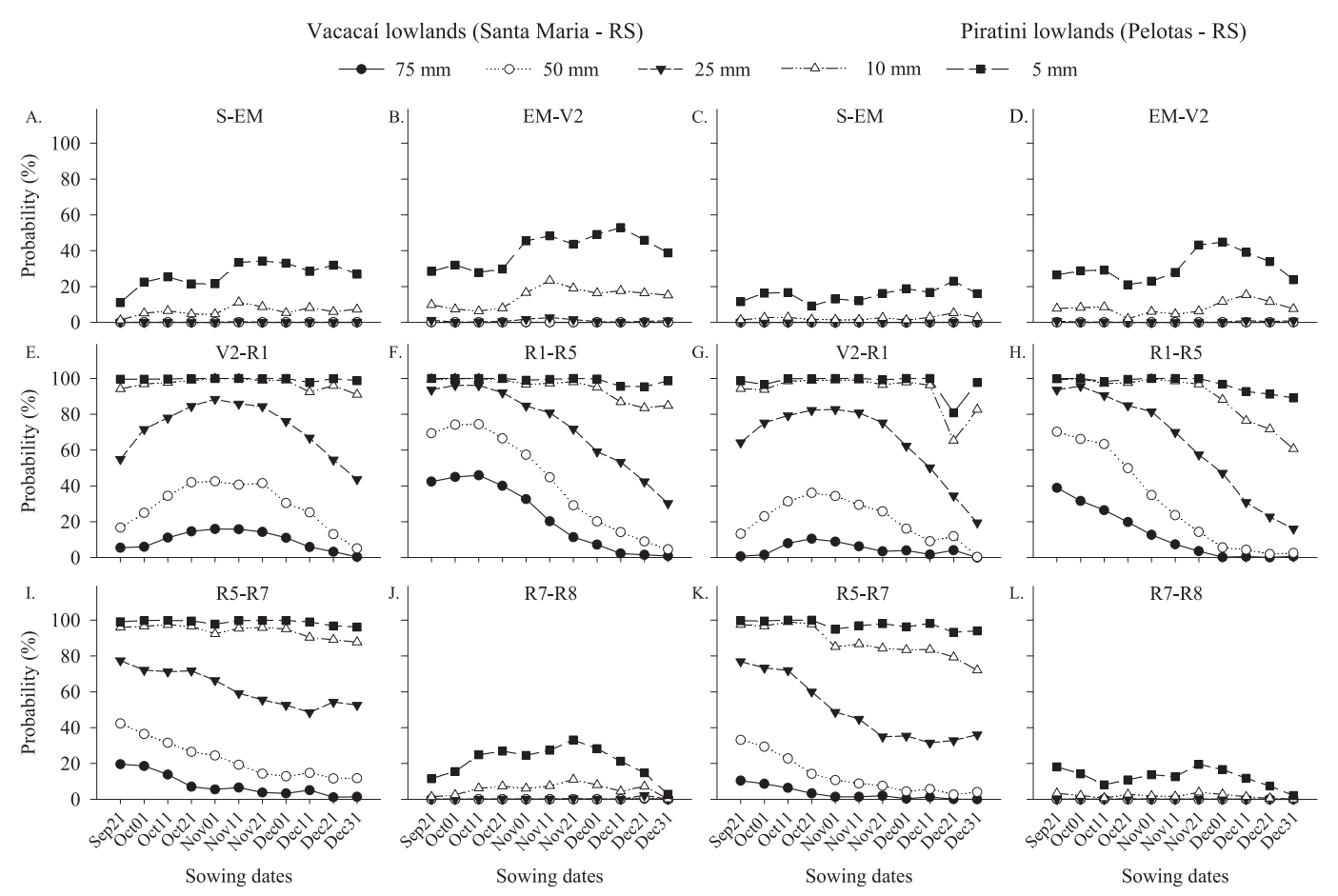

FIG. 4. As in Fig. 3, but for relative maturity group 6.9-7.3.

with the sowing dates performed in October, mainly for the WD levels of 25, 50, and $75 \mathrm{~mm}$ for all RMG (Figs. 3f, 4f, and 5f). There is a linear decrease in probability values for all RMG starting from 1 November. Similar results were obtained for the subperiod comprising the period between anthesis and milk stage of maturation in maize, where simulated sowing dates up to the beginning of November presented the greatest water deficit (deficit fraction) (Nied et al. 2005).

For the Pelotas coverage area, the probability of 5 and $10 \mathrm{~mm}$ WD occurring in the R1-R5 subperiod were close to $100 \%$ until the sowing of 21 November, with subsequent reduction regardless of the RMG (Figs. 3h, 4h, and 5h). With regard to the occurrence probabilities of 50 and $75 \mathrm{~mm}$, there is a reduction of the first sowing (21 September) until the one of 1 December, when they become inexpressive for all the RMG.

In general, the risk of WD occurrence in the R1-R5 subperiod is lower for RMG 7.4-8.0 cultivars for both Santa Maria (Fig. 5f) and Pelotas (Fig. 5h). Initially, this can be considered an advantage, acknowledging the importance of water deficit occurrence in the reproductive period. However, these lower values of probability are associated to the shorter duration of this subperiod (Trentin et al. 2013). This can be also considered a risk factor with shortened plant recovery time in case of stress occurrence.

For the R5-R7 subperiod, there is leaf senescence induction and physiological maturation is anticipated when the plants are subjected to water deficit (De Souza et al. 1997), resulting in reduced seed size and yield (Brevedan and Egli 2003). There were no differences between sowing dates and RMG for the occurrence of at least 5 and $10 \mathrm{~mm}$ of WD in the R5-R7 subperiod in Santa Maria, where the probability values were close to $100 \%$ (Figs. $3 \mathrm{i}, 4 \mathrm{i}$, and $5 \mathrm{i}$ ). Moreover, there is a linear trend decreasing from the first (21 September) to the last sowing date (31 December) for the other levels of risk of water deficit (25, 50 , and $75 \mathrm{~mm}$ ). Note that from 1 November, the risk of $75 \mathrm{~mm}$ of WD in this subperiod is extremely low.

Observing the data obtained for Pelotas, we can infer that there is a lower risk of water deficit in the R5-R7 subperiod in comparison to Santa Maria. As observed for the R1-R5 subperiod, the sowing performed in October is the one with the highest risk of occurrence of water deficit (Figs. 3k, 4k, and $5 \mathrm{k}$ ). The risk of $10 \mathrm{~mm}$ WD occurrence is reduced for sowing dates from 1 November to 31 December, where the probability is close to $80 \%$. At the other extreme, the probability of $75 \mathrm{~mm}$ or more of water deficit occurrence is insignificant from October and on while the risk of $50 \mathrm{~mm} \mathrm{WD}$ is less than $20 \%$.

The occurrence of water deficit between the seed physiological maturity R7 and R8 stages is less important to define the moment of sowing because of the small influence on the final yield, with only a small chance of seed weight reduction (Karam et al. 2005). Anyhow, sowing performed from the second half of December presented the lowest probability of WD occurrence at this stage due to coincidence with a period of reduced atmospheric demand. Therefore, issues related to the inadequate soil moisture condition for machine traffic ability and seed moisture for mechanized harvesting may be more frequent in these sowing dates. 


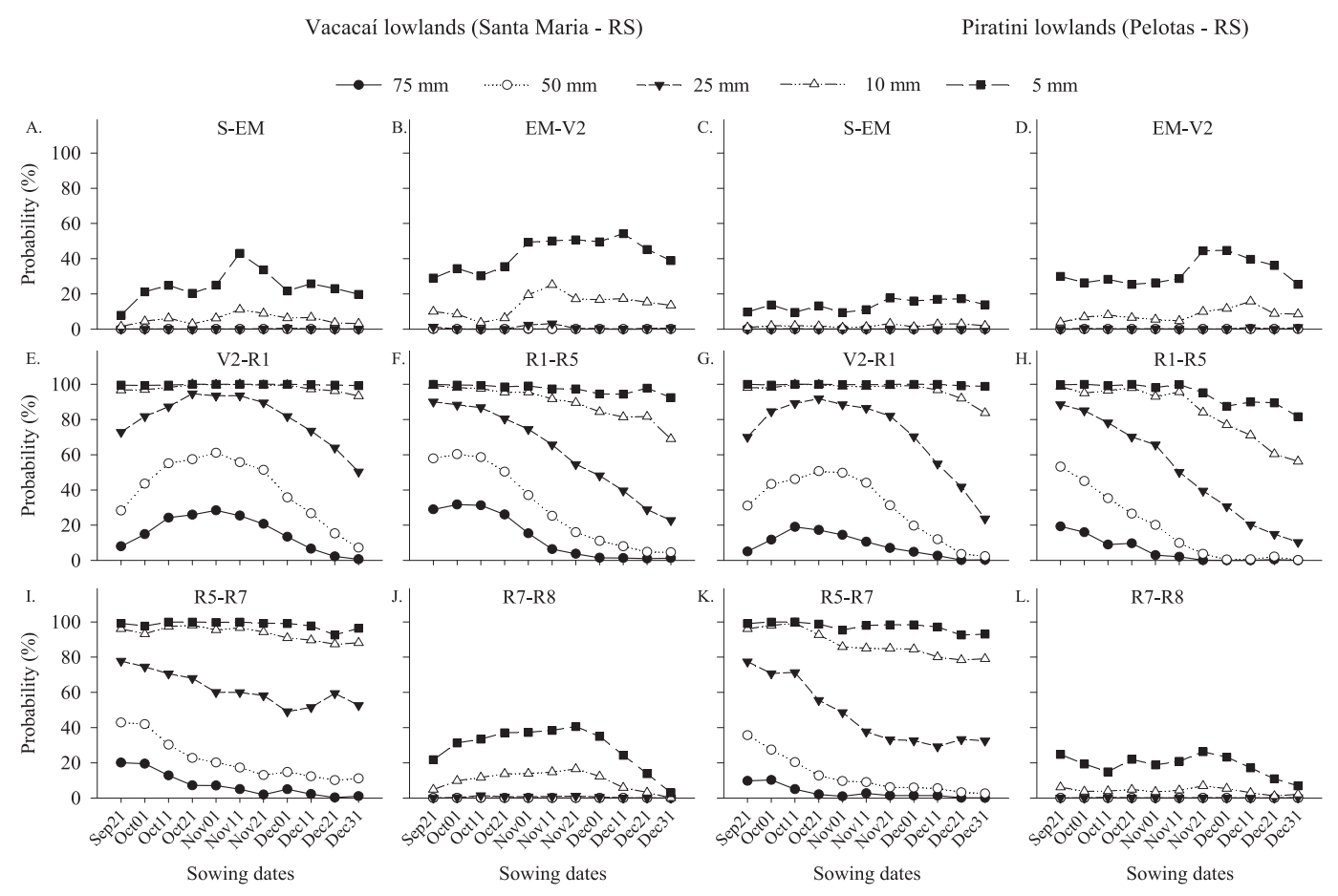

FIG. 5. As in Fig. 3, but for relative maturity group 7.4-8.0.

The highest soybean yield values in lowland found by Mundstock et al. (2017) in Santa Vitória do Palmar in the Pelotas coverage area occurred in sowing dates from 1 November to 15 November Rocha et al. (2018) indicated that the period between 15 October and 15 November is preferential for soybean sowing in lowlands in the southern portion of RS, considering that the highest yields are obtained in this interval, both at potential and experimental level and at the level of commercial fields. There is a yield reduction up to $50 \mathrm{~kg} \mathrm{ha}^{-1} \mathrm{day}^{-1}$ for sowings after 15 November, increasing the yield gap between potential yield and the one obtained in commercial fields.

The lower yield observed in sowing carried out before 15 October in fields and experiments (Rocha et al. 2018) can be related to the higher occurrence of water excess (Bortoluzzi et al. 2017) and of water deficit, which are more frequent and pronounced than for sowing performed at the end of October and November, according to our current findings. Furthermore, sowing performed at the end of September is subject to low soil temperature conditions, which hinders the formation of a uniform and adequate plant population. Also, caution should be taken with the use of RMG below 5.9 cultivars, which may be induced to early flowering due to a short photoperiod, limiting plant growth (Zanon et al. 2015).

The sowing date window indicated as preferential (from 15 October to 15 November) corroborates the historical climatic information generated regarding the occurrence of water deficit, which stands among the main factors related to yield reduction in lowland areas. Despite having high productivity potential (Zanon et al. 2016), sowing before 15 October should be avoided to reduce the risk of yield losses, since sowing dates from 11 November in the region of Santa Maria and 1 November in the Pelotas region are the ones that present a lower risk of occurrence of water deficit. In addition, the lowest risk of occurrence of water excess in the soybean cycle and initial establishment occurs from 1 November (Bortoluzzi et al. 2017) for the region of Santa Maria. We also recommend that sowing in the second half of October should be carried out only in fields with management practices that are already consolidated, while the first half of November should be prioritized by the farmers who are starting their activities in the lowland areas.

\section{Conclusions}

The water deficit is lower in the lowlands of the Piratini River basin in the Pelotas region than in the Santa Maria catchment area. Sowing dates from 11 November and 1 November present the lowest risk of water deficit during the soybean development cycle in Santa Maria and Pelotas, respectively.

Sowing dates near the summer solstice present a greater risk of inadequate water supply for crop establishment. Considering the R1-R5 and R5-R7 reproductive subperiods, there is a reduction in the risk of water deficit from 1 November, with sowing dates between 11 and 21 November presenting lower risk jointly with higher yield potential.

Acknowledgments. This work was performed with financial support from the National Council for Scientific and Technological 
Development $(\mathrm{CNPq})$ and the Coordination for the Improvement of Higher Education Personnel (CAPES).

\section{REFERENCES}

Allen, R. G., L. S. Pereira, D. Raes, and M. Smith, 1998: Crop evapotranspiration: Guidelines for computing crop water requirements. FAO Irrigation and Drainage Paper 56, 300 pp., www.fao.org/docrep/X0490E/X0490E00.htm.

Alvares, C. A., J. L. Stape, P. C. Sentelhas, J. L. M. Gonçalves, and G. Sparovek, 2013: Köppen's climate classification map for Brazil. Meteor. Z., 22, 711-728, https://doi.org/10.1127/09412948/2013/0507.

Battisti, R., P. C. Sentelhas, J. A. L. Pascoalino, H. Sako, J. P. S. Dantas, and M. F. Moraes, 2018: Soybean yield gap in the areas of yield contest in Brazil. Int. J. Plant Prod., 12, 159-168, https://doi.org/10.1007/s42106-018-0016-0.

Bortoluzzi, M. P., A. B. Heldwein, R. Trentin, D. D. P. Lucas, E. Z. Righi, and M. Leonardi, 2017: Risk of water surplus in soybean crop on haplic planosol soil in the Central Depression of Rio Grande do Sul State, Brazil. Cienc. Rural, 47, 20160170 , https://doi.org/10.1590/0103-8478cr20160170.

Boyer, C. N., M. Stefanini, J. A. Larson, S. A. Smith, A. Mengistu, and N. Bellaloui, 2015: Profitability and risk analysis of soybean planting date by maturity group. Agron. J., 107, 22532262, https://doi.org/10.2134/agronj15.0148.

Brevedan, R. E., and D. B. Egli, 2003: Short periods of water stress during seed filling, leaf senescence, and yield of soybean. Crop Sci., 43, 2083-2088, https://doi.org/10.2135/cropsci2003.2083.

Cunha, G. R., N. A. Barni, J. C. Haas, J. R. T. Maluf, R. Matzenauer, A. Pasinato, M. B. M. Pimentel, and J. L. F. Pires, 2001: Zoneamento agrícola e época de semeadura para soja no Rio Grande do Sul. Rev. Bras. Agrometeor., 9, 446-459.

De Souza, P. I., D. B. Egli, and W. P. Bruening, 1997: Water stress during seed filling and leaf senescence in soybean. Agron. J., 89, 807-812, https://doi.org/10.2134/agronj1997.00021962008900050015x.

Dourado Neto, D., A. G. Garcia, A. L. Francelli, J. A. Frizzone, and K. Reichardt, 1999: Balance hídrico ciclico y secuencial: estimación de almacenamiento de agua en el suelo. Sci. Agric., 56, 537-546, https://doi.org/10.1590/S0103-90161999000300005.

Eck, H. V., A. C. Mathers, and J. T. Musick, 1987: Plant water stress at various growth stages and growth and yield of soybeans. Field Crops Res., 17, 1-16, https://doi.org/10.1016/03784290(87)90077-3.

Gubiani, P. I., E. A. Müller, A. Somavilla, A. L. Zwirtes, R. P. Mulazzani, and E. Marchesan, 2018: Transpiration reduction factor and soybean yield in low land soil with ridge and chiseling. Rev. Bras. Ciênc. Solo, 42, 1-14, https://doi.org/10.1590/ $18069657 \mathrm{rbcs} 20170282$.

Karam, F., R. Masaada, T. Sfeirb, O. Mounzerc, and Y. Rouphael, 2005: Evapotranspiration and seed yield of field grown soybean under deficit irrigation conditions. Agric. Water Manage., 75, 226-244, https://doi.org/10.1016/j.agwat.2004.12.015.

Martorano, L. G., H. Bergamaschi, R. T. Faria, and G. A. Dalmago, 2012: Decision strategies for soil water estimations in soybean crops subjected to no-tillage and conventional systems, in Brazil. Problems, Perspectives and Challenges of Agricultural Water Management, M. Kumar, Ed., InTech, 439453, http://doi.org/10.5772/29711.

Mundstock, C. M., and Coauthors, 2017: Soja 6.000 Manejo para Alta Produtividade em Terras Baixas. IRGA, $68 \mathrm{pp}$.

Nied, A. H., A. B. Heldwein, V. Estefanel, J. C. Silva, and C. M. Alberto, 2005: Épocas de semeadura do milho com menor risco de ocorrência de deficiência hídrica no município de Santa Maria, RS, Brasil. Cienc. Rural, 35, 995-1002, https:// doi.org/10.1590/S0103-84782005000500003.

Pereira, A. R., N. A. Villa Nova, and G. C. Sediyama, 1997: Evapo(transpi)ração. FEALQ, 183 pp.

Ribeiro, P. L., A. L. Bamberg, D. A. Reis, and A. C. B. Oliveira, 2016: Condições físico-hídricas de Planossolo cultivado com soja em plantio direto. Pesqui. Agropecu. Bras., 51, 1484-1491, https://doi.org/10.1590/s0100-204x2016000900047.

Rocha, T. S. M., N. A. Streck, A. J. Zanon, E. Marcolin, M. T. Petry, E. L. Tagliapietra, D. Barlest, and K. P. Bexaira, 2017: Performance of soybean in hydromorphic and non hydromorphic soil under irrigated or rainfed conditions. Pesqui. Agropecu. Bras., 52, 293-302, https://doi.org/10.1590/s0100204x2017000500002.

—_, and Coauthors, 2018: Época de semeadura para reduzir a lacuna de produtividade de soja em terras baixas no Rio Grande do Sul. VIII Congresso Brasileiro De Soja, Goiânia, Brazil, Embrapa, 353-355, https://ainfo.cnptia.embrapa.br/digital/bitstream/item/ 178745/1/CBSoja-2018.pdf.

Schneider, F. M., G. A. Buriol, A. B. Heldwein, P. A. Manfron, A. V. Saccol, and V. Estefanel, 1987: Temperatura base e soma térmica do subperíodo semeadura emergência para algumas cultivares de soja (Glycine max (L.) Merrill). Rev. Cent. Ciênc. Rurais, 17, 299-308.

Sentelhas, P. C., R. Battisti, G. M. S. Câmara, J. R. B. Farias, A. C. Hampf, and C. Nendel, 2015: The soybean yield gap in Brazil-Magnitude, causes and possible solutions for a sustainable production. J. Agric. Sci., 153, 1394-1411, https:// doi.org/10.1017/S0021859615000313.

Setiyono, T. D., A. Weiss, J. Specht, A. M. Bastidas, K. G. Cassman, and A. Dobermann, 2007: Understanding and modeling the effect of temperature and day length on soybean phenology under high-yield conditions. Field Crops Res., 100, 257-271, https://doi.org/10.1016/j.fcr.2006.07.011.

Silva, C. M., F. Mielezrski, D. V. Chaves, E. A. Lima, J. H. Costa Filho, and A. V. Silva, 2018: Sowing seasons $\times$ maturity groups on quantitative traits in soybean. Afr. J. Agric. Res., 13, 7-13, https://doi.org/10.5897/AJAR2017.12717.

Silva, J. C., A. B. Heldwein, S. Z. Radons, I. C. Maldaner, G. Trentin, and E. L. Grimm, 2011: Necessidade de irrigação para o feijoeiro na região central do Rio Grande do Sul. Rev. Bras. Eng. Agric. Ambient., 15, 1030-1036, https://doi.org/ 10.1590/S1415-43662011001000006.

Sinclair, T. R., 1986: Water and nitrogen limitations in soybean grain productivity. I. Model development. Field Crops Res., 15, 125-141, https://doi.org/10.1016/0378-4290(86)90082-1.

—, S. Kitani, K. Hinson, J. Bruniard, and T. Horie, 1991: Soybean flowering date: Linear and logistic models based on temperature and photoperiod. Crop Sci., 31, 786-790, https:// doi.org/10.2135/cropsci1991.0011183X003100030049x.

_, L. R. Salado-Navarro, G. Salas, and L. C. Purcell, 2007: Soybean yields and soil water status in Argentina: Simulation analysis. Agric. Syst., 94, 471-477, https://doi.org/10.1016/j.agsy.2006.11.016.

Sionit, N., and P. J. Kramer, 1977: Effect of water stress during different stages of growth of soybean. Agron. J., 69, 274-278, https://doi.org/10.2134/agronj1977.00021962006900020018x.

Streck, E. V., N. Kämpf, R. S. D. Dalmolin, E. Klamt, P. C. Nascimento, and P. Schneider, 2008: Solos do Rio Grande do Sul. 2nd ed. EMATER/RS, 222 pp.

Streck, N. A., G. M. de Paula, C. Camera, N. L. Menezes, and I. Lago, 2008: Estimativa do plastocrono em cultivares de soja. Bragantia, 67, 67-73, https://doi.org/10.1590/S0006-87052008000100008. 
- - F. B. Oliveira, A. P. Schwantes, and N. L. Menezes, 2009: Improving node number simulation in soybean. Pesqui. Agropecu. Bras., 44, 661-668, https://doi.org/10.1590/S0100204X2009000700002.

Thornthwaite, C. W., and J. R. Mather, 1955: The Water Balance. Publications in Climatology, Vol. 8, Drexel Institute of Technology Laboratory of Climatology, $104 \mathrm{pp}$.

Trentin, R., A. B. Heldwein, N. A. Streck, G. Trentin, and J. C. Silva, 2013: Subperíodos fenológicos e ciclo da soja conforme grupos de maturidade e datas de semeadura. Pesqui. Agropecu. Bras., 48, 703-713, https://doi.org/10.1590/S0100204X2013000700002.

Villalobos-Rodriquez, E., and R. Shibles, 1985: Response of determinate and indeterminate tropical soybean cultivars to water stress. Field Crops Res., 10, 269-281, https://doi.org/ 10.1016/0378-4290(85)90033-4.

Wijewardana, C., K. R. Reddy, F. A. Alsajri, J. T. Irby, J. Krutz, and B. Golden, 2018: Quantifying soil moisture deficit effects on soybean yield and yield component distribution patterns. Irrig. Sci., 36, 241-255, https://doi.org/10.1007/s00271-018-0580-1.

Zanon, A. J., and Coauthors, 2015: Desenvolvimento de cultivares de soja em função do grupo de maturação e tipo de crescimento em terras altas e terras baixas. Bragantia, 74, 400-411, https://doi.org/10.1590/1678-4499.0043.

, N. A. Streck, and P. Grassini, 2016: Climate and management factors influence soybean yield potential in a subtropical environment. Agron. J., 108, 1447-1454, https://doi.org/10.2134/ agronj2015.0535. 